\title{
Financial development, ecological transition, and economic growth in Sub-Saharan African countries: the performing role of the quality of institutions and human capital
}

\author{
Abdoulganiour Almame Tinta ${ }^{1}$ \\ Received: 28 July 2021 / Accepted: 9 December 2021 / Published online: 23 January 2022 \\ ( ) The Author(s), under exclusive licence to Springer-Verlag GmbH Germany, part of Springer Nature 2022
}

\begin{abstract}
Even though the ecological transition is considered the next big challenge for Africa, few studies have examined its scope regardless of the massive financing that is required and the stakes on other sectors. This study analyzes the links between financial development, ecological transition, and economic growth in Sub-Saharan Africa from 1980 to 2019. The Dumitrescu and Hurlin causality tests, Pedroni and Westerlund cointegration, and the Augmented Mean Group algorithm are applied on a sample of forty-eight countries. The findings support that institutional quality and human capital are crucial, but their effects can only be observed in high-income and upper middle-income countries. The level of economic development matters, and there is a threshold beyond which the effects of renewable energies and human capital occur on the performance of the financial system. Trade openness and investments seem also to be positive and significant on ecological transition only in these countries. Furthermore, there is substitutability between non-renewable and renewable energy consumption in these countries, while in lower middle-income and low-income countries, there is complementarity. The study concludes by highlighting key policy recommendations to sustain ecological transition.
\end{abstract}

Keywords Renewable energy · Financial development · Economic growth · Augmented Mean Group · Sub-Saharan Africa

JEL Classification Q43 $\cdot \mathrm{G} 28 \cdot \mathrm{O} 55 \cdot \mathrm{R} 11$

\section{Introduction}

In view of the major environmental changes over the past decade, energy and natural resources have been at the core of several research during the past 5 years. Irreversible ecological degradation, financial crises, population growth, drastic fall of growth in developed countries, and its negative spillover effects on developing countries raise the need to resort to new forms of energy. Indeed, the current exploitation of resources for industrial development aims to increase exports and trade, attract investment, boost financial development, support economic growth, and reduce development disparities. All these activities contribute to an abusive use

Responsible Editor: Ilhan Ozturk

Abdoulganiour Almame Tinta

aatinta@st.ug.edu.gh

1 Department of Statistics and Economics, Joseph Ki-ZERBO University, 14 PO Box 74, Ouagadougou 14, Burkina Faso of energy resources and therefore revive the relevance of the ecological transition. Moreover, financial market crisis, social unrest and economic costs following COVID-19 crisis (OECD et al. 2020), and the continuous destruction of nonrenewable resources require the use of renewable energies. Therefore, this paper investigates the links between financial development, economic growth, and ecological transition.

Most of the literature has focused on studying a single causal relationship, namely the effect of financial development on renewable energy, or the influence of renewable energy consumption on financial development and economic growth, or the interaction between environmental factors, financial development, and renewable energy. Few studies have discussed the ecological transition effect by analyzing the connection of renewable and non-renewable energy. In addition, there is bilateral causality between the variables of interest. Although many studies have highlighted the presence of this bidirectional causality, few studies have regressed it. Finally, studies addressing Sub-Saharan African countries are rare, while the area is rich in non-renewable 
energy and experiences challenges in developing renewable energies. Due to all these limitations not addressed in the literature, this study fills the gap by examining these different causalities in Sub-Saharan Africa between ecological transition, financial development, and economic growth.

Economic theories of development (Aghion and Howitt 1992; Barro and Sala-i-Martin 1997) consider labor, capital, and technology as the foundations of economic growth. Furthermore, the new growth theory includes human capital and the quality of institutions (Becker et al. 1990). However, finance holds a prominent place through technological innovation and trade facilitation. Natural resources through the manufacturing sector, the funding of green technologies, and the transformation of non-renewable resources into renewable resources (Khan et al. 2021a, b) generate significant investments that affect banks, stock markets, factor productivity, financial system stability, and therefore financial development. Thus, the nexus between ecological transition and economic growth necessarily encompasses the financial development.

The financial system in Sub-Saharan Africa is characterized by the predominance of banking and financial institutions over financial markets. The rate of bank deposits and loans to the private sector increased by $19.1 \%$ and $9.4 \%$, respectively, between 2000 and 2019 in low-income countries of Sub-Saharan Africa. This increase is greater in the middle-income countries as it stands at $33.2 \%$ and $19.7 \%$. Between 2004 and 2011, the share of the population holding a bank account quadrupled in low-income countries and doubled in middle-income countries due to mobile banking diffusion. Despite these developments, households and businesses (especially SMEs) have poor access to financial services. Achieving the Sustainable Development Goals requires substantial financial investments, of several trillions of dollars per year (Bertho 2014), which will be used to support change and new technological solutions to succeed ecological transition. The need to guide the existing financial system towards the required investments for ecological transition, regardless of the weak and unstable real growth, leads to further investigation of the relationship between financial development and economic growth.

Suitable for analyzing complex relationships and possible causal links, the Augmented Mean Group (AMG) algorithm, recently developed by Bond and Eberhardt (2013), is used in this paper. Employing a panel data of 48 Sub-Saharan African countries over the period 1980-2019, the AMG method is useful as it addresses bias or root mean square errors in panels with nonstationary variables (cointegrated or not) and multifactor error terms (cross-section dependence). The results shows that human capital and institutional quality play a driving role in the nexus between ecological transition, financial development, and economic growth. From the findings, relevant policies targeting urbanization, trade openness, financial structures, and institutions are provided to improve ecological transition.

This study is organized as follows. The "Literature review" section presents a summary of theoretical studies and recent empirical literature. The "Methodology" section covers the methodology such as data, model, variables, and estimation procedures. The "Results and discussion" section analyzes the findings and discusses the main implications, and the "Conclusion" section completes the study.

\section{Literature review}

\section{Theoretical literature}

Economic theory analyzes the link between finance and growth through ecological transition using the environmental approach of the Kuznets curve (Forsen 2020) which postulates the existence of an inverted U-shaped relation between economic development and environmental degradation. The idea is that economic development first leads to environmental degradation, but reaching some threshold of economic growth, environmental degradation starts to decrease. However, if countries adopt this strategy, long before reaching the initial phase of development that will lead to degradation reduction, the damage to the ecosystem from the initial environmental deterioration will be irreversible. Therefore, some suggested an alternative way to increase economic growth without any impact on the environment. In this dynamic, Jason and Kallis (2019), through the green growth theory, highlighted that economic growth can be boosted by investing in clean and resource-saving technologies.

Among the kinds of clean technologies, renewable energies (hydro, wind, solar, biomass, geothermal, ocean) constitute an inexhaustible energy resource, but to achieve the transformation, large-scale investments are crucial, therefore creating the theoretical investment-ecology-growth loop. Four hypotheses have been established: (i) the growth hypothesis stating that energy consumption through the production process improves economic growth (Odugbesan and Rjoub 2020; Zhe et al. 2021; Usman et al. 2021), (ii) the conservation hypothesis reporting that economic growth leads to an increase or decrease in energy demand (Gaies et al. 2019; Shahbaz et al. 2021), (iii) the feedback hypothesis formulating that there is a bidirectional causality between growth and energy consumption (Aimer 2020), (iv) and the neutrality hypothesis saying that there is no link (Maji et al. 2019).

On the other side, financial development promotes advanced technological innovations (Cheng et al. 2020), reduces credit constraints, develops infrastructure, and stimulates industrialization (Lu et al. 2021). The direct 
consequence is the increase in jobs and incomes for consumers and lower financial charges for firms which in turn increase investments in renewable energy production. Indirectly, this induces an increase in energy consumption.

\section{Empirical literature}

The existing empirical literature agrees on a positive link between financial development and growth although different measures of financial development are used. Therefore, this section focuses on recent studies on the nexus between financial development and renewable energy and the nexus between economic growth and renewable energy, where the findings are mixed and divergent.

\section{Financial development and energy}

Raza et al. (2020) investigated the nexus between financial development and ecological transition in countries with high renewable energy consumption, using the PSTR technique from 1997 to 2017. They confirmed that financial development, measured by industrial structures, had a significant non-linear and positive effect on renewable energy consumption. Similarly, Wang and Dong (2021) explore the linear and non-linear impacts of financial development on renewable energy, using G20 countries data from 2005 to 2018 . Constructing a fixed-effect model and a panel threshold model, they find no significant linear relationships between financial development and renewable energy consumption. However, financial development has a positive and significant non-linear impact on renewable energy consumption when urbanization and technology are above a certain threshold value. Employing dynamic estimator in 21 developing countries from 1970 to 2018, Khan et al. (2021a, b) found that the sources of renewable energy enhance environmental quality as compared to non-renewable energy, but financial development lowers environmental quality.

Razmi et al. (2020), performing an ARDL approach from 1990 to 2014, used stock market development as a proxy of financial development and showed that it positively affects all kinds of renewable energy consumption (nuclear, wind, hydro, and solar) in Iran. Examining countries with high renewable energy consumption, Cheng et al. (2020) use threshold models from 1997 to 2017 and point out that financial development, measured by market capitalization, private loans, and deposits, accelerates growth in countries that have successfully made ecological transition. Including institutional quality and foreign direct investment, Khan et al. (2021a, b), using generalized method of moments from a global panel between 2002 and 2019, add that the institutional quality moderates the negative effect of financial development on environmental quality.
Studying renewable energy, economic growth, and financial development in Turkey over the period 1990-2015 with VAR analysis, Zhe et al. (2021) identified that renewable energy has a positive impact on financial development, measured by stock traded and bank loans given as a percentage of GDP. Also, Nkalu et al. (2020) analyzed financial development (proxied by domestic credit to the private sector) and energy consumption in Sub-Saharan Africa. Using a panel vector error correction model (VECM), cointegration, and Granger causality tests from 1975 to 2017, the results support a positive and significant relationship between financial development and energy consumption in the long run, but not in the short run. Lahiani et al. (2021) investigate the influence of financial development on renewable energy consumption in the United States from 1975 to 2019 with the non-linear autoregressive distributed lags (NARDL) model. Using three measures of financial development, the results show that positive and negative changes in overall and stockbased financial development measures dictate renewable energy consumption in the long run. Nevertheless, in the short run, only negative changes of overall and stock-based financial development measures significantly impact renewable energy consumption.

Lu et al. (2021) explore the link between financial development, foreign direct investment, energy consumption, and globalization for a selected panel of Belt and Road Initiative (BRI) countries over the period 1990-2016. They highlighted a unidirectional causal relationship from energy consumption to financial development. Moreover, energy consumption is boosted by economic growth and reduced by financial development. In contrast, Shahbaz et al. (2021) investigate how financial development affects renewable energy consumption. Using 34 upper middle-income developing countries from 1994 to 2015 and fully modified OLS (FMOLS) approach, they conclude that financial development promotes renewable energy demand, while economic growth declines renewable energy consumption.

\section{Energy and economic growth}

Empirical studies on the connection between renewable energy and economic growth are contradictory. Using Granger causality tests and error correction model, Kahia et al. (2017) in MENA countries, and Amri (2017) on a panel data of 72 countries, establish a positive and bidirectional causality between renewable energy and short- or long-term growth. Their findings also show a substitutability between renewable and non-renewable energy. Cetin and Ecevit (2018) in middle-income countries from 1991 to 2014 and Balsalobre-Lorente et al. (2018) in the EU over the period 1985 to 2016, using ARDL test and a VECM model, conclude that renewable energies have a positive and stronger influence on growth than non-renewable energies. 
Economies characterized by the consumption of renewable energy experience higher growth than countries using fossil fuels. Pao and Chen (2019) through a panel regression in the G20 countries add that renewable, hydraulic, and nuclear energies contribute to the stability of growth which improves energy efficiency and again generates sustainable growth.

Magazzino (2018) investigates the link between energy consumption, real income, financial development, and oil prices in Italy over the period 1960-2014. Performing the GMM estimator, the ARDL test, and causality tests such as Toda-Yamamoto and Granger, he found a long-run relationship between the variables and a unidirectional causality from real GDP to energy consumption. Ali et al. (2020) analyzed the potential of renewable energy on economic growth in 100 countries including politically free, partly free, and not free countries from 1995 to 2017. They proved a bidirectional causality and a positive impact of the ecological transition on growth in politically free and partly free countries. They stress that countries must increase investments in ecological transition and support renewable energy to secure sustainable growth. Odugbesan and Rjoub (2020) examine the synergy among economic growth, carbon dioxide emissions, urbanization, and energy consumption in Mexico, Indonesia, Nigeria, and Turkey from 1993 to 2017. Employing the ARDL approach, they indicated a unidirectional causality from energy consumption for Nigeria and Indonesia, whereas Mexico and Turkey followed the feedback hypothesis.

Nevertheless, some rare studies evidenced that ecological transition decreases growth. Sinha et al. (2018), studying 11 countries from 1990 to 2016 using the Granger test, show that ecological transition negatively affects growth in low-income countries. They argue that due to investment costs and promotion in the initial phase of renewable energy, economic growth declines. Sasana and Ghozali (2017), using data on BRICS countries from 1995 to 2014, reach the same conclusion. Moreover, Aimer (2020), using the fixed and random effect tests from 1990 to 2015, found a negative relationship between renewable energy consumption and economic growth in the MENA countries. In addition, there is a bidirectional causality between economic growth and renewable energy consumption.

A last category of studies supports the neutrality hypothesis, indicating that there is no effect between ecological transition and economic growth. Belaid and Youssef (2017), from 1980 to 2012 in Algeria, Destek and Aslan (2017) in 12 emerging countries, and Taghvaee et al. (2017) in Iran, from 1981 to 2012, found an insignificant coefficient between renewable energy consumption and growth. In addition, examining the causality between ecological transition and economic growth in 19 countries of EU over the period 1994 to 2015, Karhan (2019) underlines that the role of renewable energy on growth and vice versa is unstable.

\section{Methodology}

\section{Theoretical and econometric specifications}

To investigate the linkages between financial development, ecological transition, and economic growth in Sub-Saharan Africa, an extended Cobb-Douglas production function is used:

$Y=F(A, K, L, E, e)$

where $Y, A, K, L, E$, and $e$ denote production, technology, capital stock, labor, energy, and the error term, respectively.

Energy is divided into renewable and non-renewable energy. Technological innovation relates to accumulation of resources and is influenced by financial development, human capital, and investments in R\&D including foreign and domestic investments. Moreover, technical progress is stimulated by industrialization. Therefore, international trade through openness ratio, as highlighted by growth theories, can also be a determinant. Energy and technology can be written as:

$E=R E+N R E$

$A=\varphi F D^{\theta} H C^{n} T O^{s} I^{m}$

where $\varphi$ is time-invariant constants and $R E, N R E, F D, H C$, $T O$, and $I$ represent renewable resource, non-renewable resource, financial development, human capital, trade openness, and investment, respectively. Including Eq. 2 and Eq. 3 into Eq. 1 can be illustrated as follows:

$Y=\partial F D^{\alpha_{1}} H C^{\alpha_{2}} T O^{\alpha_{3}} I^{\alpha_{4}} K^{\alpha_{5}} L^{\alpha}(R E+N R E)^{\alpha_{6}} e$

Dividing both sides by labor, we have time series under per capita terms that is transformed into log-linear form. The following equation is given.

$$
\begin{aligned}
\ln \left(\frac{Y}{L}\right)= & \tau_{0}+\tau_{1} \ln F D+\tau_{2} \ln H C+\tau_{3} \ln T O+\tau_{4} \ln I \\
& +\tau_{5} \ln \left(\frac{K}{L}\right)+\tau_{6} \ln R E+\tau_{7} \ln N R E+\varepsilon
\end{aligned}
$$

The econometric specifications examining the interactions between financial development, ecological transition, and economic growth are presented in three equations. In the first equation with real GDP per capita as dependent variable, the role of government in terms of institutional quality (IT) and urbanization (URB) is included as control variables (Khan et al. 2021a, b; Raza et al. 2020) . Indeed, most of the scholars argue that institutional quality and urbanization increase economic growth. 


$$
\begin{aligned}
G D P_{i t}= & \beta_{0}+\beta_{1} F D_{i t}+\beta_{2} H C_{i t}+\beta_{3} T O_{i t}+\beta_{4} I_{i t}+\beta_{5} k_{i t} \\
& +\beta_{6} R E_{i t}+\beta_{7} N R E_{i t}+\beta_{8} I T_{i t}+\beta_{9} U R B_{i t}+\omega_{i t}
\end{aligned}
$$

where $k_{i t}$ is capital/labor ratio or capital intensity.

In the second equation with ecological transition measured by renewable energy as dependent variable, control variables such as urbanization, institutional quality, and merchandize trade are added. The rationale is that urbanization tends to increase the use of energy (Odugbesan and Rjoub 2020; Wang and Dong 2021), while the quality of institutions and human capital determine renewable energy production and consumption (Khan et al. 2021a, b). Transport and exchanges (measured by the rate of merchandise trade) consume a lot of energy. This requires a move towards renewable energy.

$$
\begin{aligned}
R E_{i t}= & a_{0}+a_{1} F D_{i t}+a_{2} T O_{i t}+a_{3} k_{i t}+a_{4} G D P_{i t}+a_{5} N R E_{i t} \\
& +a_{6} H C_{i t}+a_{7} I T_{i t}+a_{8} M T_{i t}+a_{9} U R B_{i t}+a_{10} I_{i t}+\gamma_{i t}
\end{aligned}
$$

Institutional quality and real income per capita have been documented as key determinants of banking sector development, whereas trade openness, investment, and inflation tend to promote stock market development (Razmi et al. 2020; Zhe et al. 2021; Lahiani et al. 2021). Macroeconomic factors such as capital, government expenditure, and human capital are a precondition for infrastructure development, promoting financial development (Nkalu et al. 2020). Recent research also emphasizes the role of energy and the flows of merchandise trade as catalysts for financial development (Shahbaz et al. 2021; Lu et al. 2021; Usman et al. 2021). Therefore, the third equation with financial development as dependent variable is presented as follows:

$$
\begin{aligned}
F D_{i t}= & \delta_{0}+\delta_{1} R E_{i t}+\delta_{2} T O_{i t}+\delta_{3} k_{i t}+\delta_{4} G D P_{i t}+\delta_{5} N R E_{i t} \\
& +\delta_{6} H C_{i t}+\delta_{7} I T_{i t}+\delta_{8} M T_{i t}+\delta_{9} I_{i t}+\delta_{10} I N F_{i t} \\
& +\delta_{11} G_{i t}+\rho_{i t}
\end{aligned}
$$

where $i(1, \ldots, N)$ indicates countries; $t(1, \ldots, T)$ denotes time period; $\beta_{k}, a_{k}$, and $\delta_{k}$ are the parameters; and $\omega_{i t}, \gamma_{i t}$, and $\rho_{i t}$ are the disturbance terms supposed to be iid with a zero mean and a finite variance $\sigma^{2}$. Table 1 summarizes the notation and measurements of the variables.

\section{Data}

The data cover the period 1980-2019 and are extracted from World Development Indicators (WDI) (2020). However, data for financial development are obtained from the International Monetary Fund (IMF) (2020). The quality of institutions is provided by the Worldwide Governance (WGI) (2020). Table 2 reports the descriptive statistics and shows a low standard deviation of the variables, except urbanization, inflation, and non-renewable energies. This shows that the rate of inflation and the level of urbanization are different between African countries. Although the deviation for non-renewable energies is relatively small, it confirms that the endowment of ores, minerals, and fossil fuels differs from country to country.

This study uses annual time series data on forty-eight countries from Sub-Saharan Africa, classified into four groups as presented in Table 3.

Figure 1 shows that Mauritius, Seychelles, South Africa, and Namibia have the highest score in terms of financial development in 2019, and in contrast, Somalia and Zimbabwe have the lowest

Table 1 Variable description

\begin{tabular}{ll}
\hline Notation & Definition and measurements \\
\hline GDP & Real gross domestic product per capita in logarithm (Pao and Chen 2019; Ali et al. 2020) \\
FD & Financial development index which is defined as a combination of financial institution and financial market indicators (Cheng et al. \\
& 2020; Lahiani et al. 2021; Usman et al. 2021) \\
TO & Trade openness measured by the sum of exports and imports over GDP (Lahiani et al. 2021; Wang and Zhang 2021) \\
I & Investments measured by the sum of domestic and foreign direct investment over GDP (Lu et al. 2021; Khan et al. 2021a, b) \\
k (K/L) & Capital/labor ratio or capital intensity (Yin et al. 2021) \\
RE & Ecological transition measured by renewable energy consumption (Raza et al. 2020; Aimer 2020; Shahbaz et al. 2021; Zhe et al. \\
NRE & 2021) \\
HC & Hon-renewable energy consumption measured by energy use (kg of oil equivalent) (Amri 2017; Balsalobre-Lorente et al. 2018; Khan \\
IT & Quality of institutions measured by the aggregation of government effectiveness, political stability, corruption, rule, and regulatory \\
URB & quality (Huynh and Hoang 2019; Khan et al. 2021a, b) \\
& and Donization measured as urban population in percentage of total population (Odugbesan and Rjoub 2020; Nkalu et al. 2020; Wang \\
INF & Inflation measured by consumer price index (Mukhtarov et al. 2020) \\
Gov & Government expenditure measured by government final consumption expenditure (\% of GDP) (Le and Ozturk 2020; Khan et al. \\
2020a) & Merchandize trade (\% of GDP) (Khan et al. 2020a, b; Rehman et al. 2021) \\
MT &
\end{tabular}


Table 2 Descriptive statistics

\begin{tabular}{lllrll}
\hline & Mean & Minimum & Maximum & Std. dev & Obs \\
\hline$G D P$ & 7.683 & -0.196 & 10.627 & 1.445 & 1910 \\
$F D$ & 0.119 & 0.000 & 0.648 & 0.088 & 1880 \\
$T O$ & 0.548 & 0.000 & 3.113 & 0.396 & 1910 \\
$I$ & 0.053 & -0.286 & 1.830 & 0.187 & 1910 \\
$k$ & 0.280 & -0.024 & 27.422 & 1.702 & 1910 \\
$R E$ & 0.446 & 0.000 & 0.983 & 0.386 & 1880 \\
NRE & 1.799 & 0.000 & 2.995 & 2.107 & 1880 \\
HC & 0.026 & 0.000 & 0.405 & 0.049 & 1910 \\
$I T$ & 0.114 & -1.345 & 4.218 & 0.458 & 1880 \\
URB & 0.795 & 0.000 & 45.276 & 3.612 & 1910 \\
$I N F$ & 0.301 & -0.604 & 237.731 & 5.645 & 1895 \\
Gov & 0.128 & 0.000 & 0.922 & 0.108 & 1910 \\
MT & 0.486 & 0.000 & 2.254 & 0.335 & 1910 \\
\hline
\end{tabular}

Table 3 List of Sub-Saharan African countries

\begin{tabular}{ll}
\hline High-income countries & Mauritius, Seychelles \\
\hline Upper middle-income countries & Gabon, Equatorial Guinea, Namibia, and South Africa \\
Lower middle-income countries & Angola, Benin, Botswana, Cote d'Ivoire, Cameroon, Congo Republic, Comoros, \\
& Cabo Verde, Ghana, Kenya, Lesotho, Mauritania, Nigeria, Senegal, Sao Tome and Principe, Eswatini, Tanza- \\
& nia, Zambia, Zimbabwe \\
Burundi, Burkina Faso, Central African Republic, Congo Democratic Republic, Eritrea, Ethiopia, Guinea, The \\
Gambia, Guinea-Bissau, Liberia, Madagascar, Mali, Mozambique, Malawi, Niger, Rwanda, Sudan, Sierra \\
Leone, Somalia, South Sudan, Chad, Togo, and Uganda \\
\hline
\end{tabular}

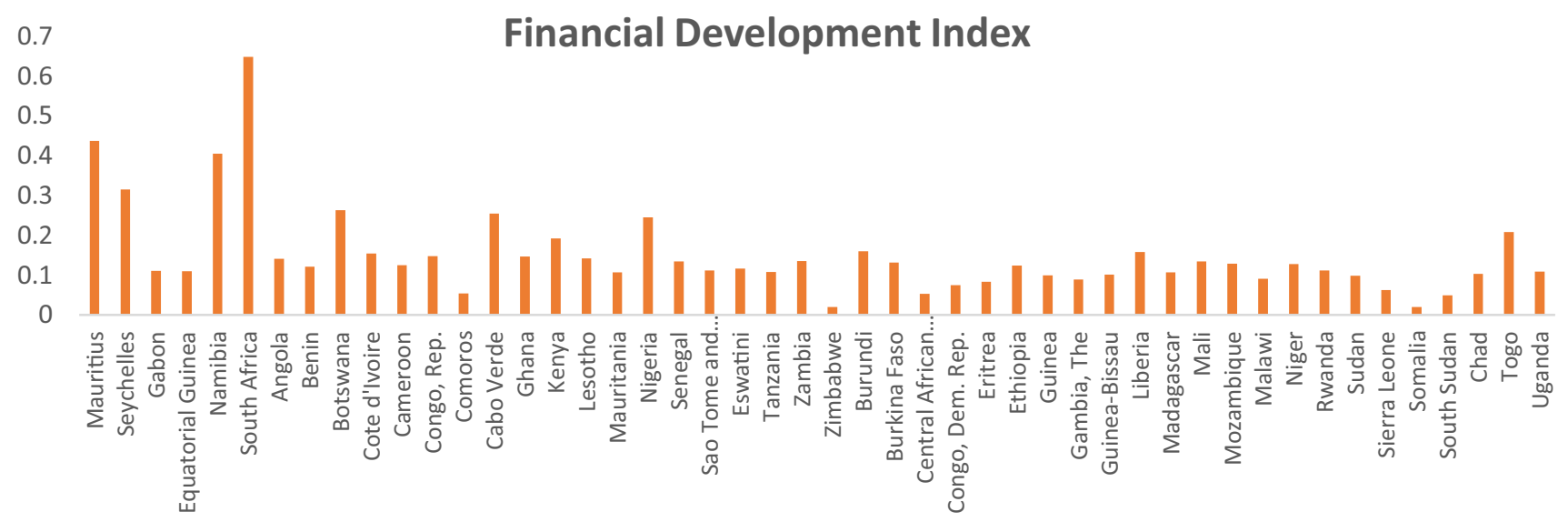

Fig. 1 Financial development index by country in 2019

score. Figure 2 illustrates the growth rate of all countries in SubSaharan Africa. In average, East and West African countries have the highest real GDP per capita growth compared to the rest of Africa. However, Equatorial Guinea, Angola, Lesotho, and Sudan have experienced a decrease in 2019. The trends of renewable energy consumption are similar for most Sub-Saharan Africans countries with island countries having the lowest rate (Fig. 3).

\section{Estimation method}

Various empirical studies use panel data with linear static models, autoregressive distributed lag (ARDL) cointegration approach, cointegration models, generalized method of moments (GMM) technique, fully modified OLS (FMOLS), dynamic OLS (DOLS), panel smooth transition regression 


\section{Real GDP growth}

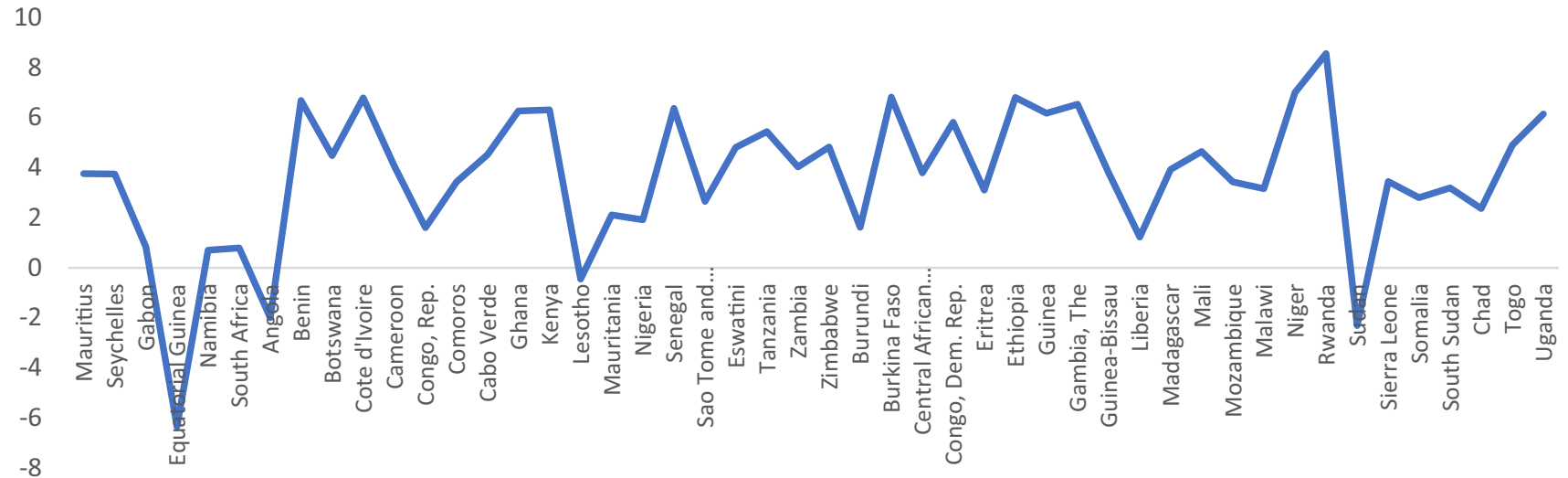

Fig. 2 Real per capita GDP growth rate by country in 2019

\section{Renewable energy consumption}

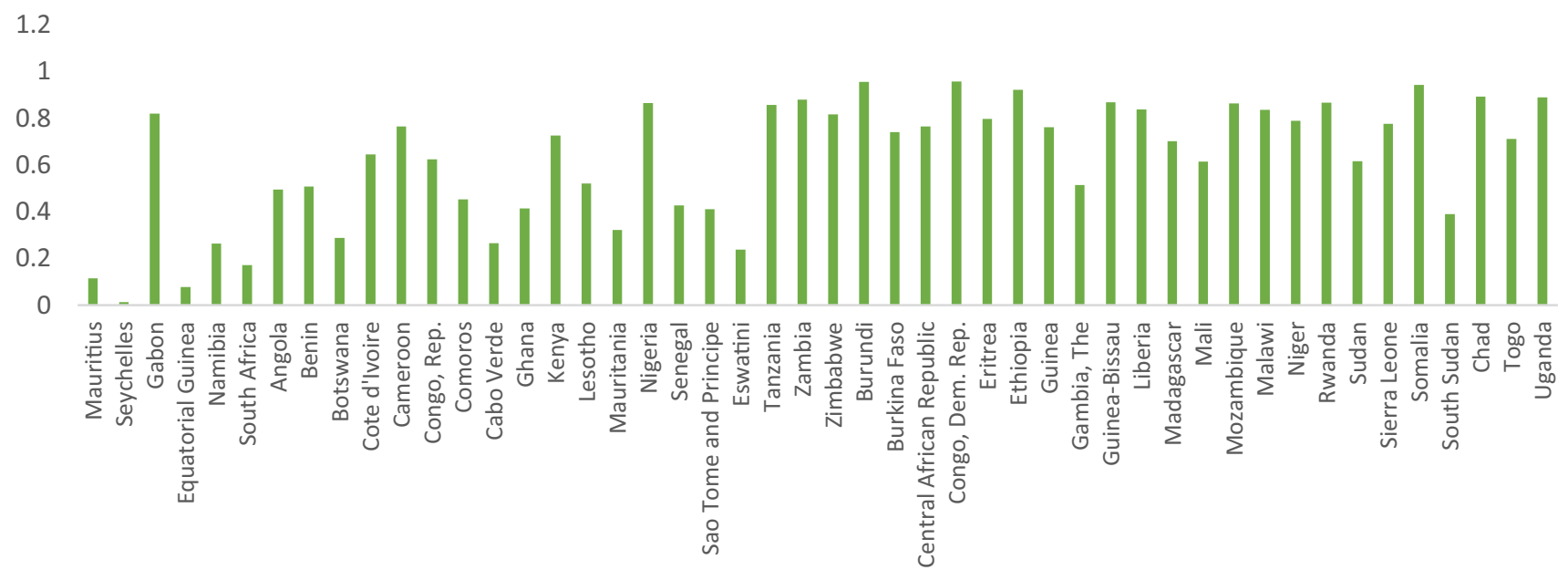

Fig. 3 Renewable energy consumption by country in 2019

(PSTR) method, Toda-Yamamoto and panel quantile regression approach, and bootstrap. In this study, three equations are performed in order to take into account the possible interactions between economic growth, financial development, and ecological transition. Therefore, among the updated methods, the algorithm of Augmented Mean Group (AMG) is applied because of the panel heterogeneity (Bond and Eberhardt 2013).
The AMG algorithm is implemented in three steps: (i) First, a pooled regression model augmented with year dummies is estimated by first difference OLS, and the coefficients collected as common dynamic process represent an estimated cross-group average of unobservable parameters over time; (ii) second, the group-specific regression model is augmented with the estimated parameters as a constraint by removing the estimated model from the dependent variable; (iii) third, the

$\left\{\begin{array}{c}G D P_{i t}=\beta_{0}+\beta_{1} F D_{i t}+\beta_{2} H C_{i t}+\beta_{3} T O_{i t}+\beta_{4} I_{i t}+\beta_{5} k_{i t}+\beta_{6} R E_{i t}+\beta_{7} N R E_{i t}+\beta_{8} I T_{i t}+\beta_{9} U R B_{i t}+\omega_{i t} \\ R E_{i t}=a_{0}+a_{1} F D_{i t}+a_{2} T O_{i t}+a_{3} k_{i t}+a_{4} G D P_{i t}+a_{5} N R E_{i t}+a_{6} H C_{i t}+a_{7} I T_{i t}+a_{8} M T_{i t}+a_{9} U R B_{i t}+a_{10} I_{i t}+\gamma_{i t} \\ F D_{i t}=\delta_{0}+\delta_{1} R E_{i t}+\delta_{2} T O_{i t}+\delta_{3} k_{i t}+\delta_{4} G D P_{i t}+\delta_{5} N R E_{i t}+\delta_{6} H C_{i t}+\delta_{7} I T_{i t}+\delta_{8} M T_{i t}+\delta_{9} I_{i t}+\delta_{10} I N F_{i t}+\delta_{11} G o v_{i t}+\rho_{i t}\end{array}\right.$ 
Table 4 Correlation results and Dumitrescu and Hurlin causality test result

\begin{tabular}{|c|c|c|c|c|c|c|c|c|c|c|c|c|c|}
\hline & $F D$ & $H C$ & $N R E$ & $I$ & $M T$ & TO & Gov & $R E$ & $U R B$ & GDP & $I N F$ & $k$ & $I T$ \\
\hline$F D$ & 1.000 & & & & & & & & & & & & \\
\hline$H C$ & 0.412 & 1.000 & & & & & & & & & & & \\
\hline NRE & 0.086 & 0.011 & 1.000 & & & & & & & & & & \\
\hline$I$ & 0.028 & 0.020 & -0.057 & 1.000 & & & & & & & & & \\
\hline$M T$ & 0.279 & 0.132 & -0.045 & 0.498 & 1.000 & & & & & & & & \\
\hline TO & 0.348 & 0.227 & -0.019 & -0.040 & 0.472 & 1.000 & & & & & & & \\
\hline Gov & 0.248 & 0.112 & -0.097 & 0.327 & 0.369 & 0.404 & 1.000 & & & & & & \\
\hline $\boldsymbol{R E}$ & -0.167 & -0.062 & 0.421 & -0.037 & -0.079 & -0.021 & -0.071 & 1.000 & & & & & \\
\hline$U R B$ & 0.007 & 0.005 & -0.057 & 0.667 & 0.276 & -0.095 & 0.474 & -0.074 & 1.000 & & & & \\
\hline$G D P$ & 0.458 & 0.305 & -0.037 & 0.182 & 0.411 & 0.424 & 0.349 & 0.220 & 0.267 & 1.000 & & & \\
\hline$I N F$ & -0.047 & -0.007 & -0.018 & -0.007 & -0.014 & -0.052 & -0.042 & -0.035 & -0.003 & -0.018 & 1.000 & & \\
\hline$k$ & 0.004 & 0.026 & -0.018 & -0.019 & -0.018 & 0.014 & -0.001 & 0.068 & -0.025 & 0.004 & 0.065 & 1.000 & \\
\hline$I T$ & 0.003 & 0.041 & -0.211 & 0.332 & 0.114 & 0.065 & -0.161 & 0.383 & 0.197 & 0.394 & -0.125 & 0.056 & 1.000 \\
\hline
\end{tabular}

Source: Author's estimation, causality from $G D P$ to $F D$, from $G D P$ and $F D$ to $R E$, from $F D$ and $R E$ to $G D P$

Table 5 Result of crosssectional dependence test

\begin{tabular}{|c|c|c|c|c|c|c|}
\hline \multirow[t]{2}{*}{ Test } & \multicolumn{2}{|l|}{ GDP } & \multicolumn{2}{|l|}{$\mathrm{RE}$} & \multicolumn{2}{|l|}{ FD } \\
\hline & Statistic & Probability & Statistic & Probability & Statistic & Probability \\
\hline Breusch-Pagan LM & 280.17 & 0.0000 & 450.21 & 0.0000 & 319.15 & 0.0000 \\
\hline Pesaran CD & 30.255 & 0.0000 & 76.668 & 0.0000 & 31.222 & 0.0000 \\
\hline
\end{tabular}

Source: author's estimation

group-specific regression parameters are averaged across the panel and therefore performing the AMG in terms of bias or root mean square errors in panels with nonstationary variables (cointegrated or not) and multifactor error terms (cross-section dependence). In this study, Dumitrescu and Hurlin (2012) test is applied in order to deal with cross-sectional dependence and heterogeneity which are one of the weaknesses of the simple ARDL approach or VECM causality test. The equation used for the test is described as:

$Y_{i t}=\alpha_{i}+\rho_{i} Y_{i t-1}+\sum_{i=1}^{p} \mu_{i}^{p} Y_{i t-n}+\sum_{i=1}^{p} \pi_{i}^{p} X_{i t-n}+\varepsilon_{i t}$

where $\mu_{i}^{p}$ and $\pi_{i}^{p}$ are the regression coefficient across countries and $Y$ and $X$ are the variables.

Before applying the AMG, cross-sectional dependence (CD) test is employed to check the null hypothesis that crosssectional data are not corelated as presented in Eq. 10.

$H_{0}: \tau_{i j}=\operatorname{correlation}\left(\varepsilon_{i t}, \varepsilon_{k t}\right)=0$

In order to avoid spurious regression, the study uses several econometric procedures to inspect the unit root tests. Both first-generation unit root tests assuming no cross-sectional dependence (Levin et al. 2002) and second-generation tests assuming cross-sectional dependence (Pesaran 2007) are used. The specification of the Levin et al. (2002) test and the cross-sectional augmented IPS test of Pesaran (2007) are shown in Eq. 11.

$$
\begin{gathered}
\Delta Y_{i t}=\gamma_{i}+\rho_{i} Y_{i t-1}+\sum_{k=1}^{p} L_{i} \Delta Y_{i t-k}+\varepsilon_{i t} \\
\Delta Y_{i t}=\gamma_{i}+\rho_{i} Y_{i t-1}+\vartheta_{i} \bar{Y}_{t-1} \sum_{k=o}^{1} L_{i k} \Delta \bar{Y}_{t-k}+L_{i 1} \Delta Y_{i t-1}+\varepsilon_{i t}
\end{gathered}
$$

Among the various tests used for cointegration, this paper chooses the Pedroni (2004) test which assumes no crosssectional dependence and the Westerlund (2007) test which handles cross-sectional dependence through bootstrapping to generate robust critical standards.

\section{Results and discussion}

The correlation results are reported in Table 4 with Dumitrescu and Hurlin (2012) causality test. The correlation analysis shows that economic growth is positively associated with renewable energy. Financial development has a negative relationship with renewable energy and inflation. Renewable energy is positively linked with non-renewable energy consumption, capital intensity, and institutional quality.

The findings of cross-sectional dependence tests are reported in Table 5, using both Pesaran and Breusch-Pagan 
Table 6 Result of first-generation unit root and second-generation cross-sectional augmented

\begin{tabular}{|c|c|c|c|c|c|c|c|c|}
\hline \multirow[t]{3}{*}{ Variables } & \multicolumn{4}{|c|}{$\begin{array}{l}\text { First-generation } \\
\text { Levin }\end{array}$} & \multicolumn{4}{|c|}{ Second-generation cross-sectional augmented IPS } \\
\hline & \multicolumn{2}{|l|}{ Intercept } & \multicolumn{2}{|c|}{ Intercept and trend } & \multicolumn{2}{|l|}{ Intercept } & \multicolumn{2}{|c|}{ Intercept and trend } \\
\hline & Levels & First diff & Levels & First diff & Levels & First diff & Levels & First diff \\
\hline$F D$ & -1.112 & $-40.14 * * *$ & -2.408 & $-37.93 * * *$ & -1.872 & $-4.138 * * *$ & -2.172 & $-6.423 * * *$ \\
\hline$H C$ & -0.024 & $-48.76^{* * *}$ & -7.773 & $-45.10 * * *$ & -1.112 & $-5.814 * * *$ & -1.614 & $-5.339 * * *$ \\
\hline$N R E$ & -0.393 & $-31.30 * * *$ & 3.169 & -30.23 & -0.929 & $-6.760 * * *$ & -1.771 & $-5.326^{* * *}$ \\
\hline$I$ & $-11.57 * * *$ & $-57.40 * * *$ & $-14.30 * * *$ & $-53.54 * * *$ & -1.972 & $-3.249 * * *$ & -1.513 & $-7.365^{* * *}$ \\
\hline$M T$ & $-3.479 * * *$ & $-42.88 * * *$ & $-3.984 * * *$ & $-40.49 * * *$ & -0.939 & $-6.215^{* * *}$ & -2.987 & $-8.373 * * *$ \\
\hline TO & $-2.247 * *$ & $-42.97 * * *$ & $-5.716^{* *}$ & $-40.01 * * *$ & -0.104 & $-5.318^{* * *}$ & -1.950 & $-9.234 * * *$ \\
\hline Gov & $-4.039 * * *$ & $-39.07 * * *$ & $-3.403^{* * *}$ & $-36.83 * * *$ & -2.319 & $-5.709 * * *$ & -2506 & $-5.299 * * *$ \\
\hline$R E$ & $-2.335^{* *}$ & $-38.23 * * *$ & $6.149 * *$ & $-39.64 * * *$ & -1.179 & $-4.511 * * *$ & -2.306 & $-7.213 * * *$ \\
\hline$U R B$ & 33.12 & $-64.13 * * *$ & -3.463 & $-169.50 * * *$ & -1.568 & $-4.126 * * *$ & -2.421 & $-4.244 * * *$ \\
\hline$G D P$ & 7.192 & $-32.02 * * *$ & 0.931 & $-30.48 * * *$ & -1.403 & $-3.477 * * *$ & -2.947 & $-6.235^{* * *}$ \\
\hline$I N F$ & $-14.94 * * *$ & $-49.87 * * *$ & $-17.45^{* * *}$ & $-46.40 * * *$ & -2.427 & $-3.404 * * *$ & -2.705 & $-3.190 * * *$ \\
\hline$K$ & $-8.175 * * *$ & $-40.51 * * *$ & $-8.540 * * *$ & $-38.07 * * *$ & -0.437 & $-4.705^{* * *}$ & -2.555 & $-5.251 * * *$ \\
\hline$I T$ & -0.514 & $-23.38 * * *$ & -5.196 & $-37.83 * * *$ & -2.479 & $-4.137 * * *$ & -2.878 & $-7.038 * * *$ \\
\hline
\end{tabular}

*** and $* *$ denote the significance level of $1 \%$ and $5 \%$, respectively. Source: author's estimation

Table 7 Result of Pedroni and Westerlund panel cointegration test

\begin{tabular}{|c|c|c|c|c|c|c|c|c|}
\hline \multirow[t]{3}{*}{ Pedroni } & \multicolumn{4}{|c|}{ Within-dimension } & \multirow{2}{*}{\multicolumn{2}{|c|}{$\frac{\text { Between-dimension }}{\text { Statistics }}$}} & \multicolumn{2}{|l|}{ Westerlund } \\
\hline & \multicolumn{2}{|l|}{ Statistics } & \multicolumn{2}{|c|}{$\begin{array}{l}\text { Weighted } \\
\text { statistics }\end{array}$} & & & \multirow[t]{2}{*}{ Statistic $Z$-value } & \multirow[t]{2}{*}{ Robust $p$ value } \\
\hline & Stat & Prob & Stat & Prob & Stat & Prob & & \\
\hline V-Statistic & -2.011 & 0.021 & -1.837 & 0.033 & GDP (Eq. a) & & Group mean & \\
\hline Rho-Statistic & -3.083 & 0.001 & -4.606 & 0.000 & -0.736 & 0.015 & 4.015 & 0.034 \\
\hline PP-Statistic & -2.514 & 0.004 & -4.105 & 0.000 & -2.430 & 0.010 & Panel mean & \\
\hline ADF-Statist & -0.113 & 0.078 & -1.442 & 0.040 & 0.288 & 0.021 & -5.637 & 0.040 \\
\hline V-Statistic & 3.798 & 0.000 & 3.448 & 0.000 & RE (Eq. b) & & Group mean & \\
\hline Rho-Statistic & -6.204 & 0.000 & -8.231 & 0.000 & -8.661 & 0.000 & 3.212 & 0.000 \\
\hline PP-Statistic & -6.395 & 0.000 & -8.385 & 0.000 & -9.773 & 0.000 & Panel mean & \\
\hline ADF-Statist & -3.094 & 0.001 & -3.872 & 0.000 & -4.835 & 0.000 & -6.971 & 0.000 \\
\hline V-Statistic & -3.779 & 0.000 & -5.805 & 0.000 & FD (Eq. c) & & Group mean & \\
\hline Rho-Statistic & 2.637 & 0.096 & 3.480 & 0.000 & 3.019 & 0.099 & 4.985 & 0.030 \\
\hline PP-Statistic & 0.800 & 0.088 & 0.798 & 0.078 & -1.072 & 0.042 & Panel mean & \\
\hline ADF-Statist & 3.412 & 0.000 & 2.733 & 0.097 & 1.723 & 0.058 & -3.117 & 0.019 \\
\hline
\end{tabular}

Source: author's estimation tests for each equation. All the tests reject the null hypothesis which confirms a cross-sectional dependence.

The first-generation unit root test of Levin et al. (2002) and the second-generation cross-sectional augmented IPS test of Pesaran (2007) results are given in Table 6. The findings indicate that all variables are integrated at first order.

The results of the cointegration test for each equation $(a, b$, and c) confirm that the specification of each model is robust. Moreover, there is a long-run stable relationship between $G D P$ as dependent variable and selected control variables, between $R E$ as dependent variable and the explanatory variables, and between $F D$ as dependent variable and its determinants. Pedroni and Westerlund cointegration test, provided in Table 7 , indicate that a single vector exists for each equation. All coefficients are significant; therefore, the model as specified in the study is unbiased.

Tables 8, 9, and 10 show the results of the Augmented Mean Group algorithm estimation. To highlight the interaction between financial development, ecological transition, and economic growth in Sub-Saharan Africa, each equation is analyzed. The findings are reported for all Sub-Saharan African countries and then disaggregated into high, upper 
Table 8 AMG results, ecological transition, and financial development effects on economic growth

\begin{tabular}{|c|c|c|c|c|c|}
\hline $\begin{array}{l}\text { Dep. var } \\
\text { GDP (a) }\end{array}$ & Sub-Saharan Africa & High-income countries & $\begin{array}{l}\text { Upper middle- } \\
\text { income countries }\end{array}$ & $\begin{array}{l}\text { Lower middle-income } \\
\text { countries }\end{array}$ & Low-income countries \\
\hline$F D$ & $0.552 * *(0.031)$ & $0.876^{* * *}(0.000)$ & $0.698 * * *(0.000)$ & $0.425^{* *}(0.024)$ & $0.207 * *(0.039)$ \\
\hline TO & $0.222 * *(0.034)$ & $0.701 * *(0.040)$ & $0.611 * *(0.029)$ & $0.335^{* *}(0.043)$ & $0.299 * *(0.022)$ \\
\hline$k$ & $0.058 *(0.074)$ & $0.114 *(0.058)$ & $0.101 *(0.060)$ & $0.090 * *(0.004)$ & $0.077 * *(0.049)$ \\
\hline$I$ & $0.188^{* *}(0.028)$ & $0.310 * *(0.042)$ & $0.300 * *(0.035)$ & $0.281 * *(0.040)$ & $0.207 * *(0.015)$ \\
\hline$R E$ & $0.016 *(0.084)$ & $0.172 * *(0.035)$ & $0.187 * *(0.011)$ & $0.017 *(0.094)$ & $0.009 *(0.072)$ \\
\hline$N R E$ & $0.313 * *(0.044)$ & $0.625^{* *}(0.020)$ & $0.588 * *(0.032)$ & $0.495^{* * *}(0.001)$ & $0.518 * * *(0.008)$ \\
\hline$H C$ & $0.170 *(0.056)$ & $0.501 * *(0.031)$ & $0.482 * *(0.041)$ & $0.346^{* *}(0.048)$ & $0.233 * *(0.032)$ \\
\hline$I T$ & $0.354 *(0.075)$ & $0.497 * *(0.025)$ & $0.476 * *(0.019)$ & $0.308(0.177)$ & $0.219(0.258)$ \\
\hline$U R B$ & $0.082(0.377)$ & $0.170(0.248)$ & $0.151(0.206)$ & $0.209(0.420)$ & $0.193(0.391)$ \\
\hline \multicolumn{6}{|c|}{ Diagnostic test: $p$ value } \\
\hline & Serial correlation & Heteroscedasticity & Normality & Model specification & \\
\hline LM test & 0.334 & & & & $R$-squared $=0.512$ \\
\hline BPG tes & & 0.655 & & & $F$-statistic $=59.56$ \\
\hline Jarque- & & & 0.413 & & $\operatorname{Prob}(F)=0.000$ \\
\hline Ramsey & & & & 0.255 & \\
\hline
\end{tabular}

$* * *, * *$, and $*$ denote the significance level of $1 \%, 5 \%$, and $10 \%$, respectively; the probabilities values are in parentheses. Source: author's estimation

Table 9 AMG results, economic growth, and financial development effects on ecological transition

\begin{tabular}{|c|c|c|c|c|c|}
\hline $\begin{array}{l}\text { Dep. var } \\
\text { RE (b) }\end{array}$ & Sub-Saharan Africa & High-income countries & $\begin{array}{l}\text { Upper middle-income } \\
\text { countries }\end{array}$ & $\begin{array}{l}\text { Lower middle-income } \\
\text { countries }\end{array}$ & Low-income countries \\
\hline$F D$ & $0.572 * *(0.020)$ & $0.714 * *(0.011)$ & $0.590 * *(0.023)$ & $0.328 * *(0.030)$ & $0.100 * *(0.042)$ \\
\hline TO & $0.109(0.259)$ & $0.447 * * *(0.000)$ & $0.335^{* * *}(0.000)$ & $-0.070(0.405)$ & $-0.138(0.420)$ \\
\hline$K$ & $0.333 *(0.073)$ & $0.294 * *(0.018)$ & $0.207 * *(0.034)$ & $0.205^{*}(0.090)$ & $0.180 *(0.079)$ \\
\hline$G D P$ & $0.183 * *(0.025)$ & $0.240 * *(0.011)$ & $0.207^{* *}(0.021)$ & $0.016 *(0.070)$ & $0.010 *(0.052)$ \\
\hline$N R E$ & $0.056^{* * *}(0.000)$ & $-0.249 * *(0.044)$ & $-0.165^{* *}(0.047)$ & $0.126 * *(0.019)$ & $0.045 * *(0.032)$ \\
\hline$H C$ & $0.320 * *(0.041)$ & $0.606^{* *}(0.021)$ & $0.500 * *(0.024)$ & $0.210 * *(0.014)$ & $0.062 * *(0.033)$ \\
\hline$I T$ & $0.139 * * *(0.002)$ & $0.203^{* *}(0.045)$ & $0.108 * *(0.025)$ & $0.076(0.222)$ & $0.055(0.442)$ \\
\hline$M T$ & $0.066(0.001)$ & $0.167(0.212)$ & $0.120(0.191)$ & $0.043(0.329)$ & $0.080(0.382)$ \\
\hline$U R B$ & $0.048 *(0.057)$ & $0.275^{* *}(0.025)$ & $0.173 * *(0.025)$ & $0.054 *(0.044)$ & $0.077 *(0.068)$ \\
\hline$I$ & $0.110 *(0.089)$ & $0.226 * *(0.025)$ & $0.214 * *(0.017)$ & $-0.154 * *(0.036)$ & $-0.179 * *(0.017)$ \\
\hline \multicolumn{6}{|c|}{ Diagnostic test: $p$ value } \\
\hline & Serial correlation & Heteroscedasticity & Normality & Model specification & \\
\hline LM test & 0.633 & & & & $R$-squared $=0.687$ \\
\hline BPG test & & 0.278 & & & $F$-statistic $=123.56$ \\
\hline Jarque-Bera & & & 0.222 & & $\operatorname{Prob}(F)=0.000$ \\
\hline Ramsey test & & & & 0.541 & \\
\hline
\end{tabular}

$* * *, * *$, and $*$ denote the significance level of $1 \%, 5 \%$, and $10 \%$, respectively; the probabilities values are in parentheses. Source: author's estimation

middle, lower middle, and low-income countries. In Table 8, the findings indicate that overall, economic growth in SubSaharan Africa is driven by financial development, trade openness, investments, capital intensity, renewable and non-renewable energy consumption, human capital, and the quality of institutions. An increase of financial development, trade openness, investments, capital intensity, human capital, and renewable and non-renewable energy consumption by $1 \%$ rises economic growth by $0.552 \%, 0.222 \%, 0.188 \%$, $0.058 \%, 0.170 \%, 0.016 \%$, and $0.313 \%$, respectively. Furthermore, the rise of the institutional quality by 1 point enhances growth by $0.354 \%$. Our findings are in line with those of 
Table 10 AMG results, ecological transition, and economic growth effects on financial development

\begin{tabular}{|c|c|c|c|c|c|}
\hline $\begin{array}{l}\text { Dep. var } \\
\text { FD (c) }\end{array}$ & Sub-Saharan Africa & High-income countries & Upper middle-income countries & $\begin{array}{l}\text { Lower middle- } \\
\text { income countries }\end{array}$ & Low-income countries \\
\hline$R E$ & $0.058 *(0.066)$ & $0.725 * *(0.042)$ & $0.672 * *(0.030)$ & $0.304(0.138)$ & $0.270(0.289)$ \\
\hline TO & $0.774 * *(0.028)$ & $0.658 * * *(0.000)$ & $0.558 * * *(0.000)$ & $0.466 * *(0.020)$ & $0.442 * *(0.017)$ \\
\hline$k$ & $0.127 * *(0.044)$ & $0.132 * *(0.014)$ & $0.096^{* *}(0.039)$ & $0.057 * *(0.037)$ & $0.013 * *(0.040)$ \\
\hline$G D P$ & $0.877 * *(0.016)$ & $0.794 * * *(0.003)$ & $0.590 * * *(0.007)$ & $0.508 * *(0.041)$ & $0.499 * *(0.034)$ \\
\hline$N R E$ & $0.588 * *(0.027)$ & $-0.180 * * *(0.00)$ & $-0.201 * * *(0.006)$ & $0.344 * * *(0.003)$ & $0.328 * * *(0.008)$ \\
\hline$H C$ & $0.430 * *(0.042)$ & $0.523 * * *(0.000)$ & $0.474 * * *(0.000)$ & $0.274(0.151)$ & $0.212(0.116)$ \\
\hline$I T$ & $0.626 * *(0.049)$ & $0.617 * * *(0.004)$ & $0.580 * * *(0.008)$ & $0.479 * *(0.039)$ & $0.411 * *(0.045)$ \\
\hline$M T$ & $0.222 *(0.077)$ & $0.160 *(0.060)$ & $0.151 *(0.070)$ & $0.140 *(0.066)$ & $0.136^{*}(0.073)$ \\
\hline$I$ & $0.154 *(0.058)$ & $0.327 *(0.077)$ & $0.248 *(0.075)$ & $0.244 *(0.058)$ & $0.232 *(0.088)$ \\
\hline$I N F$ & $-0.564 *(0.063)$ & $-0.370 *(0.081)$ & $-0.224 *(0.074)$ & $-0.173 *(0.084)$ & $-0.120 *(0.058)$ \\
\hline Gov & $0.275 *(0.054)$ & $0.237 *(0.059)$ & $0.186^{*}(0.067)$ & $0.132 *(0.051)$ & $0.158 *(0.083)$ \\
\hline \multicolumn{6}{|c|}{ Diagnostic test: $p$ value } \\
\hline & Serial correlation & Heteroscedasticity & Normality & Model specification & \\
\hline$L M$ test & 0.778 & & & & $R$-squared $=0.745$ \\
\hline BPG test & & 0.199 & & & $F$-statistic $=202.71$ \\
\hline $\begin{array}{l}\text { Jarque- } \\
\text { Bera }\end{array}$ & & & 0.393 & & $\operatorname{Prob}(F)=0.000$ \\
\hline Ramsey test & & & & 0.606 & \\
\hline
\end{tabular}

$* * *, * *$, and $*$ denote the significance level of $1 \%, 5 \%$, and $10 \%$, respectively; the probabilities values are in parentheses. Source: author's estimation

Mohamed (2021) who supports that local-level reforms need to develop domestic financial system and take full advantage of the technology transfer induced by international trade. He highlighted that trade openness works as a complement to financial development.

Regional policies must be improved to facilitate trade in Africa. Although regional integration agreements are multiplying, the true level of openness of African economies remains low. This is due to the many barriers at the borders and the high intra-regional transaction costs. Indeed, Africa is the continent where intra-trade is more expensive than extra-trade. As pointed out by Tinta et al. (2018), intra-African trade is only around 10 percent. To improve trade openness, we recommend, first, the increase in transport and communications infrastructure which is the main handicap for trade and, second, the digitization of payment procedures to speed up customs checks. These measures will help reduce red tape and reduce corruption. These measures will ease red tape and reduce corruption, which in turn will improve the quality of institutions.

In addition, the findings reveal that human capital and investments in Sub-Saharan Africa contribute significantly to boost the economy, which is also stimulated by capital intensity. This shows that African economies are far from a steady state and the education mechanism affects economic growth. African policies must increase investments in human capital, innovation, and technology to improve the quality of human resources. This will strengthen the labor market in Africa and therefore increase the productivity of factors driving growth. As highlighted by Diebolt and Hippe (2019) in explaining current regional disparities in innovation and economic development in Europe, human capital was the key factor and had important persisting effects on economic development.

The impact of renewable energy on growth is low which displays that the countries depend heavily on non-renewable energy (fossil energy). Nuclear energy facing many challenges in Africa and requiring a huge initial investment, South Africa is the only country with nuclear energy generation capacity although Namibia, Niger, and Malawi are involved in global uranium production. Therefore, fossil energy is the most widely used, especially oil and natural gas, which many countries have in reserve. This finding is corroborated by Ali et al. (2020) who emphasize that the weak effect of ecological transition on growth in politically free and partly free countries is associated with the lack of investment. In view of the high investment costs, we suggest a gradual transition to solar and wind energy, which is growing in West Africa.

The disaggregated results clearly indicate that although the contribution of renewable energy to growth is low in general, it is relatively greater in high-income (0.172) and upper middle-income (0.187) countries compared to lower middle-income (0.017) and low-income countries (0.009). This 
evidences that in high-income and upper middle-income countries, renewable energies are replacing non-renewable energies, although in these economies the exploitation of non-renewable energies is also higher than in lower middle- and low-income economies. This ecological transition positively affects growth, as all the coefficients are higher in advanced economies. For instance, in Southern and Eastern Africa, the use of traditional biomass predominates, associated with the use of biofuels for the production of electricity which reached $1.8 \mathrm{GW}$ in $2019 .{ }^{1}$ In addition, solar technologies are growing on the continent with $2.4 \mathrm{GW}$ only in South Africa, followed by Ghana, Nigeria, and Kenya. All these transformations explain the differences in the two regimes.

Furthermore, comparing the results between the four groups, it appears that the quality of institutions is not significant in lower middle-income and low-income countries which suggests that the results do not validate that institutional quality promotes economic growth in less advanced economies. This outcome is counterintuitive but can be explained by institutional failures, conflicts, sociopolitical instability, and corruption in these countries. Indeed, the relationship between institutional quality and economic growth is debated in the literature. While Glaeser et al. (2004) support that the institutions do not directly affect economic growth and the effects depend on corruption, Bonnal and Yaya (2015) document that institutional quality does not affect economic growth. Our findings are also in line with Kemoe and Lartey (2021) and Wandeda et al. (2021) who underline that the effect of institutional quality on output varies in Sub-Saharan African countries with less effectiveness in Eastern and Central Africa. As a policy recommendation, decision-makers should strengthen institutions through anti-corruption measures, government bureaucracies' removal, and citizen involvement in the development agenda to increase transparency.

To conclude, human capital and institutional quality play a driving role in the nexus between ecological transition, financial development, and economic growth.

Table 9 establishes that in Sub-Saharan Africa, a rise in financial development of $1 \%$ improves the ecological transition by $0.572 \%$, confirming that the development of banks and financial institutions favors the green economy. Wang and Dong (2021) found similar results for G20 countries. Although the banking sector is emerging in Africa and financial technologies are spreading across the continent, accessibility remains limited. Many regions remain not covered by a banking institution. We recommend the consolidation of the financial system by reducing the costs of financial transactions and enabling financial products to the vulnerable layers. The financial sector must also be more open to increase competition.

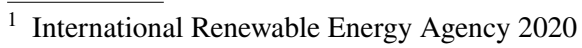

A $1 \%$ increase of economic growth, capital intensity, and investment results in a $0.183 \%, 0.333 \%$, and $0.110 \%$ raise in ecological transition, respectively. This proves that economic dynamics and capital movements boost renewable energies. This is supported by Rehman et al. (2021), Khan et al. (2020a), and Lu et al. (2021) who argue that industrialization is essential for the energy transformation process. In addition, infrastructure development is a necessary condition to facilitate the adoption of renewable energies. Indeed, an improvement in urbanization of $1 \%$ is accompanied by a growth in the consumption of renewable energies of $0.048 \%$. This positive and significant effect of urbanization on renewable energy is also supported by Odugbesan and Rjoub (2020) in Mexico, Indonesia, Nigeria, and Turkey.

Moreover, ecological transition is reinforced by the quality of institutions and human capital respectively by $0.110 \%$ and $0.320 \%$ which is corroborated by Khan et al. (2021a, b) and Yin et al. (2021). Pata and Caglar (2021) demonstrated that increasing human capital improved ecological transition and reduced environmental degradation in China. Finally, our results display that overall, in sub-Saharan Africa, the consumption of non-renewable resources increases that of renewable resources (0.056). This outcome can be attributed to infrastructures, insufficient for the exploitation of natural resources. The installations in the majority of African countries do not allow the extraction of the necessary quantity of non-renewable energy. The exploitation of resources is done at the limit of the power of the equipment, hence the need to resort to renewable energy for the complement. This positive relationship can also mean an overexploitation of resources and therefore a transition to renewable energies.

However, these findings and global discussions for SubSaharan Africa show some disparities at the regional level. First, the effects of trade openness and investments seem to be positive and significant on ecological transition only in high-income (0.447 and 0.226) and upper middle-income countries $(0.335$ and 0.214$)$, whereas in lower middleincome and low-income countries, trade openness is not significant, and investments decrease ecological transition $(-0.154$ and -0.179$)$. As expected, in weak economies, the level of trade openness is low, which explains the insignificant effect on renewable energies. On the contrary, investments in these countries are directed towards sectors that have no link with energy transformation or have very little effect on the ecology. In the majority of these countries, all sectors are generally considered a priority, and investments very often are absorbed in the wrong sectors, which does not produce spillover effects on the whole economy. Investments slow down ecological transition. It is therefore necessary that these countries invest in technology, innovation, and industries to establish the preconditions for the transformation of energies. 
Similarly, Alam and Murad (2020) found that trade openness significantly influences ecological transition in the long term in OECD countries. Comparing developing and developed countries, Khan et al. (2021a, b) show that trade openness improves ecology in developed countries while degrading the quality of environment in developing countries.

Second and not surprisingly, the quality of institutions has no effect on ecological transition in lower middle-income and low-income countries. This analysis is a logical extension of our previous discussions on the quality of institutions in these countries. Third, in high-income $(-0.249)$ and upper middle-income $(-0.165)$ countries, there is substitutability between non-renewable and renewable energy, highlighting that effort is being made by government to control the consumption of non-renewable resources and therefore promote green energy. In contrast, in low-income (0.045) and lower middle-income $(0.126)$ countries, there is complementarity between the two types of energy, non-renewable energies being the most used. Kahia et al. (2017) present similar findings in MENA countries.

To sum up, this study confirms the feedback hypothesis between ecological transition and economic growth in Sub-Saharan Africa. In high-income and upper middleincome countries, the power of the production system and the spinning of factories are leading these countries to resort more to renewable energies. In lower middle- and low-income countries, due to their inability to support the costs, growth weakly affects renewable energy consumption. Furthermore, investments and trade openness are not favorable to green energy development.

Analyzing the determinants of financial development in Sub-Saharan Africa, as projected in Table 10, all the variables are significant and have signs in accordance with the literature. When economic growth, renewable energy, and non-renewable energy improve by $1 \%$, financial development is enhanced by $0.877 \%, 0.058 \%$, and $0.588 \%$, respectively. As expected, financial development is mainly pushed by non-renewable compared to renewable energy. Among the control variables, trade openness (0.774), capital intensity (0.127), investments (0.154), merchandize trade (0.222), and government expenditure (0.275) also drive financial development. A $1 \%$ growth in human capital leads to a $0.43 \%$ jump in financial development, while an improvement in institutions by 1 point generates a financial development of $0.626 \%$. In accordance with the literature, an increase in inflation of $1 \%$ decreases financial development by $0.564 \%$. Inflation worsens the financial system as predicted by most theories. These findings are consistent with Lahiani et al. (2021), Lu et al. (2021), and Usman et al. (2021) in America and Zhe et al. (2021) in Europe. Completing the analysis of previous models, we found evidence of a bilateral causality between economic growth and financial development in Sub-Saharan Africa.
Although these clarifications concern Sub-Saharan Africa, there are however regional differences regarding the renewable and non-renewable energy effect and human capital impact. The level of economic development matters and is responsible for these discrepancies. For instance, renewable energies and human capital are crucial for financial development, but their effects can only be observed in highincome and upper middle-income countries. When renewable energies and human capital grow by $1 \%$, financial development rises by $0.725 \%$ and $0.523 \%$, respectively, in high-income countries and $0.672 \%$ and $0.474 \%$, respectively, in upper middle-income countries. This reflects the existence of a threshold beyond which the effects of renewable energies and human capital occur on the performance of the financial system. Also, $1 \%$ non-renewable energy consumption reduces financial development by $0.180 \%$ and $0.201 \%$ in high-income and upper middle-income countries, respectively. Le and Ozturk (2020) comparing poor and rich countries, and Tinta et al. (2021) comparing Sub-Saharan countries, stressed the importance of income level on the influence of variables when.

However, the effect of non-renewable energy is positive in lower middle-income and low-income countries. Increasing the use of non-renewable resources of $1 \%$ in these countries raises financial development by $0.344 \%$ and $0.328 \%$ correspondingly. As expected, this positive impact is associated with enormous rents, linked to the exploitation of natural resources, in particular oil, natural gas, coal mines, and uranium, which constitute the bulk of their wealth. This also explains the low diversification of these economies.

In short, regarding financial development, two major policies can be pursued by lower middle-income and low-income countries. The first step is to improve the quality of human resources. This improvement requires increased investment in education and the support of new initiatives. Once the quality of education is in place, it will initiate innovation which will have a positive impact on most sectors. All these changes will help stabilize growth and promote renewable energies. Second, revenues and rents from natural resources must serve the green economy as many countries in the Middle East and America have done. These investments will increase the diversification of economies and give birth to many promising sectors which will guarantee both energy and financial development. Although high-income and upper middle-income countries are on a good trajectory, they must continue to improve the quality of institutions and reduce the ineffectiveness of public policies and political conflicts. 


\section{Conclusion}

Energy plays a crucial role for economic activities and environmental issues. Indeed, all forms of raw material processing and capital and labor productivity require energy. Regardless the growing energy demand of population, an emerging alternative is the promotion of renewable energies. This ecological transition requires startup costs, operational and research costs, and infrastructure, which affects the financial system. Using the Augmented Mean Group algorithm and a sample of forty-eight countries in Sub-Saharan Africa from 1980 to 2019, this study analyzes the links between financial development, ecological transition, and economic growth. The AMG method addresses cross-section dependence and provides robust results. After performing Dumitrescu and Hurlin causality tests and unit root tests, the result of Pedroni and Westerlund cointegration shows the existence of a vector for ecological transition, financial development, and economic growth.

The findings for Sub-Saharan Africa confirm the feedback hypothesis between ecological transition and economic growth and a bidirectional causality between economic growth and financial development. First, economic growth is driven by financial development, trade openness, investments, capital intensity, renewable and nonrenewable energy consumption, human capital, and the quality of institutions. The disaggregated results evidence that in high-income and upper middle-income countries, renewable energies are replacing non-renewable energies. Also, the quality of institutions is not significant in lower middle-income and low-income countries, which do not validate that institutional quality promotes economic growth in less advanced economies.

Second, ecological transition in Sub-Saharan Africa is enhanced by financial development, economic growth, capital intensity, investment, human capital, institutional quality, urbanization, and non-renewable energies. However, these global findings show some disparities at the regional level. For instance, the effects of trade openness and investments on ecological transition is positive and significant only in high-income and upper middle-income countries, whereas in lower middle-income and low-income countries, trade openness is not significant, and investments decrease ecological transition. In addition, the quality of institutions has no effect on ecological transition in lower middle-income and lowincome countries. Finally, there is substitutability between non-renewable and renewable energy in high-income and upper middle-income countries, while in contrast, in lower middle-income and low-income countries, there is complementarity between the two types of energy.

Third, the determinants of financial development in SubSaharan Africa are economic growth, renewable energy and non-renewable energy, trade openness, capital intensity, investments, merchandize trade, government expenditure, institutional quality, human capital, and inflation. This latter decreases financial development. However, there are regional differences regarding the renewable and non-renewable energy effect and human capital impact. The level of economic development matters and is responsible for these discrepancies.

Public policy must focus on improving trade openness and investments. Especially in less advanced economies, governments must direct their spending towards the productive sectors and the revitalization of economic activity. Regional policies must be improved to facilitate trade in Africa such as the increase in transport and communications infrastructure and the digitization of payment procedures to speed up customs checks. Expanding urbanization can contribute to ease renewable energy diffusion, while improving general trade can increase financial development in Sub-Saharan Africa. Financial structures need also to be strengthened, and this study recommends the consolidation of the financial system by reducing the costs of financial transactions and enabling financial products to the vulnerable layers. The financial sector must also be more open to increase competition.

African policies must increase investments in human capital, innovation, and technology to improve the quality of human resources. Since institutions are poorly perceived, more efforts need to be provided to give credibility to institutions and make them more efficient. Decision-makers should strengthen institutions through anti-corruption measures, government bureaucracies' removal, and citizen involvement in the development agenda to increase transparency.

Drawing their wealth from the extraction of natural resources, the dependence on non-renewable energies is also strong. Ecological transition will be a long and difficult process. In view of the high investment costs, we suggest a gradual transition to solar and wind energy, which is growing in West Africa. Government must prioritize investments in these sectors and increase public awareness of the use of non-renewable energies.

As indicated in this study and the majority of previous work, although the effect of renewable energies on economic growth is significant, it remains small. This is one of the main limitations. It is obvious that financial development contributes to boosting both the ecological transition and the economic system; however, the overall added value remains limited. The big challenge with renewable energy is that the source of the energy is local and free, but all the harvesters are imported. The imports are an integral part of the FDI. For Sub-Saharan African countries, where technology is deficient, the value derived from renewable energy is exported to pay the cost of imported capital and technologies. Therefore, poverty sustains, and the jobs are all foreign and has no manufacturing content for the local population. Further research must investigate the nexus between economic growth, financial development, energy consumption, and jobs.

Acknowledgements Thank you to reviewers and editor. 
Author contribution Not applicable

Availability of data and materials The datasets used and/or analyzed during the current study are available from the corresponding author on reasonable request.

\section{Declarations}

Ethics approval and consent to participate Not applicable

Consent for publication Not applicable

Competing interests The author declares no competing interests.

\section{References}

Aghion P, Howitt P (1992) A model of growth through creative destruction. Econometrica 60(2):323-351. https://doi.org/10. $2307 / 2951599$

Aimer NM (2020) Renewable energy consumption, financial development and economic growth: evidence from panel data for the Middle East and North African countries. Econ Bull 40:20582072. http://www.accessecon.com/Pubs/EB/2020/Volume40/EB20-V40-I3-P180.pdf

Alam M, Murad W (2020) The impacts of economic growth, trade openness and technological progress on renewable energy use in organization for economic co-operation and development countries. Renew Energy 145:382-390. https://doi.org/10.1016/j. renene.2019.06.054

Ali Q, Ali R, Saadia N, Sahrish S, Iqbal MTK (2020) Potential of renewable energy, agriculture, and financial sector for the economic growth: evidence from politically free, partly free and not free countries. Renew Energy 162:934-947. https://doi.org/10. 1016/j.renene.2020.08.055

Amri F (2017) Intercourse across economic growth, trade and renewable energy consumption in developing and developed countries. Renew Sustain Energy Rev 69:527-534. https://doi.org/10.1016/j. rser.2016.11.230

Balsalobre-Lorente D, Shahbaz M, Roubaud D, Farhani S (2018) How economic growth, renewable electricity and natural resources contribute to CO2 emissions? Energy Policy 113:356-367. https:// doi.org/10.1016/j.enpol.2017.10.050

Barro RJ, Sala-i-Martin X (1997) Technological diffusion, convergence, and growth. J Econ Growth 2(1):1-26. https://doi.org/10. 1023/A:1009746629269

Becker G, Murphy K, Tamura R (1990) Human capital, fertility, and economic growth. J Polit Econ 98:12-37. https://doi.org/10.1086/ 261723

Belaiid F, Youssef M (2017) Environmental degradation, renewable and non-renewable electricity consumption, and economic growth: assessing the evidence from Algeria. Energy Policy 102:277-287. https://doi.org/10.1016/j.enpol.2016.12.012

Bertho F (2014) Renforcer les systèmes financiers des pays d'Afrique subsaharienne pour financer le futur agenda pour le développement durable. Revue D'économie Financière 116(4):81. https:// doi.org/10.3917/ecofi.116.0081

Bond S, Eberhardt M (2013) Accounting for unobserved heterogeneity in panel time series models. Nuffield College, University of Oxford, mimeo

Bonnal M, Yaya ME (2015) Political institutions, trade openness, and economic growth: new evidence. Emerg Mark Financ Trade 51(6):1-16. https://doi.org/10.1080/1540496X.2015.1011514
Cetin M, Ecevit E (2018) The dynamic causal links between energy consumption, trade openness and economic growth: time series evidence from upper middle-income countries. Eur J Econ Stud 7:58-68

Cheng CY, Chien MS, Lee CC (2020) ICT diffusion, financial development, and economic growth: an international cross-country analysis. Econ Model 94(C):662-671. https://doi.org/10.1016/j. econmod.2020.02.008

Destek MA, Aslan A (2017) Renewable and non-renewable energy consumption and economic growth in emerging economies: evidence from bootstrap panel causality. Renew Energy 111:757763. https://doi.org/10.1016/j.renene.2017.05.008

Diebolt C, Hippe R (2019) The long-run impact of human capital on innovation and economic development in the regions of Europe. Appl Econ 51(5):542-563. https://doi.org/10.1080/00036846. 2018.1495820

Dumitrescu EI, Hurlin C (2012) Testing for granger non-causality in heterogeneous panels. Econ Model 29(4):1450-1460. https://doi. org/10.1016/j.econmod.2012.02.014

Forsen E (2020) The environment Kuznets curve: investigating the relationship between renewable energy and economic growth, Uppsala universitet, 30

Gaies B, Kaabia O, Ayadi R, Guesmi K, Abid I (2019) Financial development and energy consumption: is the MENA region different? Energy Policy 135:111000. https://doi.org/10.1016/j.enpol.2019. 111000

Glaeser EL, La Porta R, Lopez-de-Silanes F, Shleifer A (2004) Do institutions cause growth? J Econ Growth 9(3):271-303. https:// doi.org/10.2139/ssrn. 556370

Huynh CM, Hoang HH (2019) Foreign direct investment and air pollution in Asian countries: does institutional quality matter? Appl Econ Lett 26(17):1388-1392. https://doi.org/10.1080/13504851. 2018.1563668

Jason H, Kallis G (2019) Is green growth possible? New Polit Econ. https://doi.org/10.1080/13563467.2019.1598964

Kahia M, Aissa MSB, Lanouar C (2017) Renewable and non-renewable energy use-economic growth nexus: the case of MENA net oil importing countries. Renew Sustain Energy Rev 71:127-140. https://doi.org/10.1016/j.rser.2017.01.010

Karhan G (2019) Does renewable energy increase growth? Evidence from EU-19 countries. Int J Energy Econ Policy 9(2):341346. https://doi.org/10.32479/ijeep.7589

Kemoe L, Lartey EKK (2021) Public debt, institutional quality and growth in sub-Saharan Africa: a threshold analysis. Int Rev Appl Econ. https://doi.org/10.1080/02692171.2021.1957785

Khan H, Itbar K, Truong TB (2020a) The heterogeneity of renewable energy consumption, carbon emission and financial development in the globe: a panel quantile regression approach. Energy Rep 6:859-867. https://doi.org/10.1016/j.egyr.2020.04.002

Khan I, Han L, Khan H, Oanh L (2021a) Analyzing renewable and nonrenewable energy sources for environmental quality: dynamic investigation in developing countries. Math Probl Eng 3399049:112. https://doi.org/10.1155/2021/3399049

Khan H, Weili L, Khan I (2021b) Institutional quality, financial development and the influence of environmental factors on carbon emissions: evidence from a global perspective. Environ Sci Pollut Res. https://doi.org/10.1007/s11356-021-16626-z

Khan H, Khan I, Oanh L, Lin Z (2020b)The dynamic interrelationship of environmental factors and foreign direct investment: dynamic panel data analysis and new evidence from the globe. Math Probl Eng:1-12. https://doi.org/10.1155/2020/2812489

Lahiani A, Mefteh-Wali S, Shahbaz M, Vo XV (2021) Does financial development influence renewable energy consumption to achieve carbon neutrality in the USA? Energy Policy 158:112524. https:// doi.org/10.1016/j.enpol.2021.112524 
Le HP, Ozturk I (2020) The impacts of globalization, financial development, government expenditures, and institutional quality on $\mathrm{CO} 2$ emissions in the presence of environmental Kuznets curve. Environ Sci Pollut Res 27(18):22680-22697. https://doi.org/10. 1007/s11356-020-08812-2

Levin A, Lin CF, Chu CSJ (2002) Unit root tests in panel data: asymptotic and finite sample properties. J Econ 108(1):1-24. https://doi. org/10.1016/S0304-4076(01)00098-7

Lu J, Imran M, Haseeb A, Saud S, Wu M, Siddiqui F, Khan MJ (2021) Nexus between financial development, FDI, globalization, energy consumption and environment: evidence from BRI countries. Front Energy Res 9:707590. https://doi.org/10.3389/fenrg.2021. 707590

Magazzino C (2018) GDP, energy consumption and financial development in Italy. Int J Energy Sect Manage 12(1):28-43. https://doi. org/10.1108/IJESM-01-2017-0004

Maji IK, Sulaiman C, Abdul-Rahim AS (2019) Renewable energy consumption and economic growth nexus: a fresh evidence from West Africa. Energy Rep 5:384-392. https://doi.org/10.1016/j. egyr.2019.03.005

Mohamed SI (2021) Trade openness, financial development and economic growth in North African countries. Int J Fin Econ:1-12. https://doi.org/10.1002/ijfe.2503

Mukhtarov S, Humbatova S, Seyfullayev I, Kalbiyev Y (2020) The effect of financial development on energy consumption in the case of Kazakhstan. J Appl Economet 23(1):75-88. https://doi.org/10. 1080/15140326.2019.1709690

Nkalu CN, Ugwu SC, Asogwa FO, Kuma MP, Onyeke QO (2020) Financial development and energy consumption in Sub-Saharan Africa: evidence from panel vector error correction model. SAGE Open 10(3). https://doi.org/10.1177/2158244020935432

Odugbesan JA, Rjoub H (2020) Relationship among economic growth, energy consumption, $\mathrm{CO} 2$ emission, and urbanization: evidence from MINT countries. SAGE Open 10(2). https://doi.org/10.1177/ 2158244020914648

OECD I et al (2020) Revenue statistics in Latin America and the Caribbean 2020, OECD Publishing, Paris. the OECD Centre for Tax Policy and Administration, the OECD Development Centre, the Inter-American Center of Tax Administrations (CIAT), the Economic Commission for Latin America and the Caribbean (ECLAC) and the Inter-American Development Bank (IDB)

Pao HT, Chen CC (2019) Decoupling strategies: $\mathrm{CO}_{2}$ emissions, energy resources, and economic growth in the Group of Twenty. J Clean Prod 206:907-919. https://doi.org/10.1016/j.jclepro.2018.09.190

Pata UK, Caglar AE (2021) Investigating the EKC hypothesis with renewable energy consumption, human capital, globalization and trade openness for China: evidence from augmented ARDL approach with a structural break. Energy 216:119220. https://doi. org/10.1016/j.energy.2020.119220

Pedroni P (2004) Panel cointegration: asymptotic and finite sample properties of pooled time series tests with an application to the PPP hypothesis. Economet Theory 20(3):597-625. https://doi.org/ $10.1017 / \mathrm{S} 0266466604203073$

Pesaran MH (2007) A simple panel unit root test in the presence of cross-section dependence. J Appl Econ 22(2):265-312. https:// doi.org/10.1002/jae.951

Raza SA, Nida S, Muhammad AQ, Shahzad Q, Ramsha A, Farhan A (2020) Non-linear threshold effect of financial development on renewable energy consumption: evidence from panel smooth transition regression approach. Environ Sci Pollut Res 27:3203432047. https://doi.org/10.1007/s11356-020-09520-7

Razmi SF, Bajgiran BR, Behname M, Salari TE, Razmi SMJ (2020) The relationship of renewable energy consumption to stock market development and economic growth in Iran. Renew Energy 145:2019-2024. https://doi.org/10.1016/j.renene.2019.06.166
Rehman A, Ma H, Ahmad M, Ozturk I, Işık C (2021) Estimating the connection of information technology, foreign direct investment, trade, renewable energy and economic progress in Pakistan: evidence from ARDL approach and cointegrating regression analysis. Environ Sci Pollut Res:1-13. https://doi.org/10.1007/ s11356-021-14303-9

Sasana H, Ghozali I (2017) The impact of fossil and renewable energy consumption on the economic growth in Brazil, Russia, India, China and South Africa. Int J Energy Econ Policy 7(3):194200. https://www.econjournals.com/index.php/ijeep/article/view/ 4926

Shahbaz M, Topcu BA, Sarıgül SS, Vo XV (2021) The effect of financial development on renewable energy demand: the case of developing countries. Renew Energy 178:1370-1380. https://doi.org/ 10.1016/j.renene.2021.06.121

Sinha A, Shahbaz M, Sengupta T (2018) Renewable energy policies and contradictions in causality: a case of Next 11 countries. J Clean Prod 197:73-84. https://doi.org/10.1016/j.jclepro.2018. 06.219

Taghvaee VM, Shirazi JK, Boutabba MA, Aloo AS (2017) Economic growth and renewable energy in Iran. Iran Econ Rev 21(4):789_ 808. https://doi.org/10.22059/ier.2017.64081

Tinta AA, Sarpong DB, Ouedraogo IM, Al Hassan R, Mensah-Bonsu A, Onumah EE (2018) The effect of integration, global value chains and international trade on economic growth and food security in ECOWAS. Cogent Food Agric 4:1465327. https://doi.org/ 10.1080/23311932.2018.1465327

Tinta AA, Ouedraogo S, Thiombiano N (2021) Nexus between economic growth, financial development, and energy consumption in Sub-Saharan African countries: a dynamic approach. Nat Res Forum:1-14. https://doi.org/10.1111/1477-8947.12240

Usman O, Alola AA, Ike GN (2021) Modelling the effect of energy consumption on different environmental indicators in the United States: the role of financial development and renewable energy innovations. Nat Res Forum:1-23. https://doi.org/10.1111/14778947.12242

Wandeda DO, Masai W, Myandemo SM (2021) Institutional quality and economic growth: evidence from Sub-Saharan Africa countries. Afr J Econ Rev 9(4):106-125

Wang Q, Dong Z (2021) Does financial development promote renewable energy? Evidence of G20 economies. Environ Sci Pollut Res Int. https://doi.org/10.1007/s11356-021-15597-5

Wang Q, Zhang F (2021) Free trade and renewable energy: a crossincome levels empirical investigation using two trade openness measures. Renew Energy 168:1027-1039. https://doi.org/10. 1016/j.renene.2020.12.065

Westerlund J (2007) Testing for error correction in panel data. Oxf Bull Econ Stat 69(6):709-748. https://doi.org/10.1111/j.14680084.2007.00477.x

Yin Y, Xiong X, Hussain J (2021) The role of physical and human capital in FDI-pollution-growth nexus in countries with different income groups: a simultaneity modeling analysis. Environ Impact Assess Rev 91:106664. https://doi.org/10.1016/j.eiar.2021.106664

Zhe L, Yüksel S, Dinçer H, Mukhtarov S, Azizov M (2021) The positive influences of renewable energy consumption on financial development and economic growth. SAGE Open 11(3). https:// doi.org/10.1177/21582440211040133

Publisher's note Springer Nature remains neutral with regard to jurisdictional claims in published maps and institutional affiliations. 